\title{
SELEKSI YANG TEPAT MEMBERIKAN HASIL YANG HEBAT
}

\author{
Didik Ariyanto \\ Balai Penelitian Pemuliaan Ikan \\ Jl. Raya 2 Pantura Sukamandi, Patokbeusi, Subang 41263, Jawa Barat \\ E-mail:didik_ski@yahoo.com
}

\begin{abstract}
ABSTRAK
Perbaikan genetik ikan melalui program pemuliaan diharapkan dapat memperbaiki kualitas induk dan benih ikan. Seleksi, sebagai sebuah metode pemuliaan, dapat dilakukan dengan berbagai cara, sesuai dengan kondisi populasi yang akan diperbaiki. Seleksi individu adalah metode seleksi paling sederhana dan mudah dilakukan. Seleksi individu akan efektif jika dilakukan pada populasi dengan nilai heritabilitas yang tinggi. Populasi dengan nilai heritabilitas rendah hingga sedang dapat diseleksi menggunakan metode seleksi famili. Tulisan ini akan memberikan gambaran tentang seberapa besar pengaruh metode seleksi berbeda yang diterapkan pada suatu populasi terhadap respons seleksi yang diperoleh. Pada tulisan ini, digunakan data yang diperoleh pada kegiatan seleksi karakter pertumbuhan ikan mas yang dilakukan di Balai Penelitian Pemuliaan Ikan (BPPI), Sukamandi.
\end{abstract}

KATA KUNCI: metode seleksi, efektivitas, respon seleksi, ikan mas

\section{ABSTRACT: The right selection method for great selected result. By: Didik Ariyanto}

Genetic improvement of fish was conducted toimprove the quality of fish broodstock. Selection as a breeding method, can be done in severa ways, in accordance with the conditions of the fish population to be improved. Individual selection is the method of selection which the most simple and easy to do. Individualselection will be effective if done in the population with high value heritability. But, populationswith low to moderate value heritability must be selected using familyselection method. This article will give you an idea of how much influence the difference selection method which applied to a population will get the responses of selection. For this, we use the data from the selection program of Common carp conducted in Research Institute for Fish Breeding (RIFB) Station in Sukamandi.

KEYWORDS: $\quad$ selection method, effectiveness, response of selection, common carp

\section{PENDAHULUAN}

Kualitas genetik suatu populasi menentukan penampilan fenotipik populasi tersebut. Populasi benih ikan dengan kualitas yang tinggi dan didukung dengan lingkungan yang baik akan memberikan hasil produksi yang maksimal (Tave, 1996). Populasi benih dengan kualitas genetik yang tinggi dapat diperoleh melalui suatu program pemuliaan. Teknik pemuliaan ikan air tawar yang banyak dikembangkan adalah teknik seleksi dengan mengeksploitasi potensi dan karakter genetis, khususnya ragam gen aditif $\left(V_{A}\right)$. Ragam gen aditif $\left(V_{A}\right)$ merupakan fungsi dari alel yang akan diturunkan melalui gamet haploid dari generasi ke generasi. Ragam gen aditif $\left(V_{A}\right)$ bersifat masingmasing gen menambah sifat-sifat tertentu dari suatu sifat, dengan kata lain setiap alel bersama-sama dengan kemampuan berbeda membentuk ragam fenotipe $\left(V_{p}\right)$. Seleksi tidak menciptakan gen baru, namun eksploitasi $V_{A}$ akan merubah frekuensi gen sehingga meningkatkan mutu genetik secara kualitatif dan kuantitatif dengan sasaran akhir adalah mendapatkan induk unggul (Tave, 1993; Hardjosubroto, 1994; Warwick et al., 1995, Tave, 1996 dan Noor, 2000).

Dari segi praktis, seleksi diartikan sebagai suatu tindakan untuk membiarkan individu atau populasi tertentu bereproduksi sedangkan individu atau populasi lainnya tidak diberi kesempatan bereproduksi (Noor, 2000). Individu atau populasi yang diseleksi bukan berdasarkan kemampuan beradaptasi dengan lingkungan tetapi berdasarkan keunggulan sifat-sifatnya, misal pertumbuhan cepat, daya tahan terhadap penyakit tinggi dan lainnya (Noor, 2000). Dalam pelaksanaanya, terdapat beberapa metode seleksi antara lain seleksi individu dan seleksi famili. Seleksi individu dilakukan dengan memilih individu-individu yang unggul dalam suatu populasi. Seleksi individu dapat diaplikasikan pada populasi dengan nilai heritabilitas tinggi tetapi tidak efektif jika diaplikasikan pada suatu populasi 
dengan nilai heritabilitas yang rendah karena akan menghasilkan respons seleksi yang rendah. Seleksi famili melibatkan banyak famili dalam suatu populasi untuk diseleksi. Modifikasi dari kedua metode seleksi tersebut menghasilkan ragam seleksi famili, yakni seleksi between family dan within family. Metode seleksi famili dapat diaplikasikan pada suatu populasi dengan nilai heritabilitas rendah (Tave, 1993; Hardjosubroto, 1994; Warwick et al., 1995 dan Noor, 2000).

Beberapa kegiatan seleksi dilakukan tanpa memperhatikan latar belakang populasi yang akan diseleksi sehingga respons seleksi yang diperoleh tidak seperti yang diharapkan. Penelitian ini bertujuan mengevaluasi metode seleksi, khususnya seleksi individu dan seleksi famili yang diaplikasikan pada suatu populasi ikan mas yang mempunyai nilai heritabilitas karakter pertumbuhan rendah.

\section{BAHAN DAN METODE}

Bahan utama dalam penelitian ini adalah populasi benih ikan mas Rajadanu populasi F0 yang dibentuk tahun 2011 dan populasi F1 ikan mas Rajadanu yang dibentuk tahun 2012. Populasi F0 dibentuk dari induk betina dan jantan ikan mas Rajadanu hasil koleksi yang diperoleh pada tahun 2010, sedangkan populasi F1 dibentuk dari induk betina tetua $(\mathrm{P})$ dengan induk jantan terseleksi dan non seleksi populasi F0 ikan mas Rajadanu.

\section{Seleksi Populasi F0 menggunakan Metode Seleksi Individu}

Duapuluh pasang induk ikan mas dipijahkan untuk membentuk populasi F0. Populasi F0 tersebut selanjutnya dipelihara secara komunal hingga mencapai ukuran calon induk selama enam bulan. Seleksi individu diaplikasikan pada populasi F0 dengan menyeleksi 20\% individu dengan bobot badan terbaik. Selain calon induk dengan bobot badan terbaik, juga dipilih 5\% individu dengan bobot badan rata-rata, yang akan digunakan sebagai populasi kontrol. Selanjutnya kedua populasi calon induk tersebut dipelihara secara terpisah baik pada populasi jantan maupun betina.

Setelah mencapai kematangan reproduksi pada umur delapan bulan, dua ekor induk jantan dari masing-masing populasi terseleksi dan populasi kontrol dipijahkan dengan induk betina tetua $(\mathrm{P})$ untuk membentuk benih uji F1-BC (back cross). Persilangan back cross dilakukan karena calon induk betina F0 belum mencapai kematangan gonad. Pada bahasan selanjutnya, populasi hasil pemijahan ini disebut sebagai populasi F1 saja. Pemijahan dilakukan dengan metode pemijahan buatan dengan bantuan hormon Ovaprim $^{\circledR}$. Metode pemeliharaan larva, pendederan benih hingga pemeliharaan tahap pembesaran kedua populasi dilakukan secara terpisah dengan metode yang sama, sesuai dengan protokol pemeliharaan ikan mas yang dikeluarkan oleh Pusat Pengembangan Induk Ikan Mas Nasional (PPIIMN, 2010). Pada akhir kegiatan pembesaran, yaitu pada umur enam bulan dilakukan pengukuran bobot badan individu pada masing-masing populasi dengan cara mengambil contoh (sample) ikan secara acak. Jumlah contoh ikan yang diambil dari masing-masing populasi sebanyak 50 ekor dengan tiga kali pengulangan.

\section{Seleksi Populasi F1 menggunakan Seleksi Famili}

Sebanyak 25 induk jantan F1 dipijahkan induk betina F0 untuk membentuk populasi F2-BC. Hal ini dilakukan karena induk betina F1 belum mencapai kematangan gonad sehingga belum bisa dipijahkan. Dalam bahasan ini, populasi F2-BC selanjutnya disebut sebagai populasi F2 saja. Populasi F2 yang terdiri atas 25 famili dipelihara secara terpisah antar famili hingga mencapai ukuran calon induk selama enam bulan. Seleksi famili dilakukan dengan model within family, yaitu memilih 50 ekor individu, terdiri atas individu jantan dan betina, dengan bobot badan terbaik dalam setiap famili. Jumlah total individu terseleksi sebanyak 1.250 ekor yang selanjutnya dipelihara secara komunal di kolam tanah, terpisah antara populasi jantan dan betina.

Setelah mencapai kematangan reproduksi pada umur delapan bulan, dua ekor induk jantan dari populasi terseleksi F1 dipijahkan dengan induk betina F0 untuk membentuk populasi benih uji F2. Selain itu, juga dilakukan pemijahan induk dua ekor jantan F0 terseleksi dengan induk betina tetua $(\mathrm{P})$ sebagai populasi kontrol. Pemijahan dilakukan secara buatan dengan bantuan hormon Ovaprim $^{\circledR}$. Metode pemeliharaan larva, pendederan benih hingga pemeliharaan tahap pembesaran kedua populasi dilakukan secara bersama dengan metode yang sama sesuai dengan protokol pemeliharaan ikan mas yang dikeluarkan oleh Pusat Pengembangan Induk Ikan Mas Nasional (PPIIMN, 2010). Pada akhir kegiatan pembesaran, yaitu pada umur enam bulan dilakukan pengukuran bobot badan individu ikan pada masing-masing populasi dengan cara mengambil contoh ikan secara acak. Jumlah contoh ikan dari masing-masing populasi sebanyak 50 ekor dengan tiga kali pengulangan.

\section{Parameter dan Analisis Data}

Data hasil pengukuran bobot badan pada ikan benih uji F1 dan F2 digunakan untuk menghitung nilai respons seleksi, heritabilitas nyata dan peningkatan genetik (genetic gain). Hasil perhitungan yang diperoleh dianalisis secara deskriptif.

\section{HASIL DAN BAHASAN}

Beberapa parameter terukur pada benih uji populasi F1 dan F2 disajikan pada Tabel 1 dan Tabel 2. Pola pertumbuhan kedua populasi benih uji berdasarkan 
Tabel 1. Analisis beberapa parameter fenotipe dan genotipe populasi F1 hasil seleksi individu F0

Table 1. Phenotype and genotype parameters of F1 population from individual selected F0

\begin{tabular}{|c|c|}
\hline Parameter / Parameters & Nilai / Values \\
\hline \multicolumn{2}{|l|}{ Bobot calon induk F0 terseleksi $(\mathrm{g})$} \\
\hline Weight of selected FO (g) & 210.22 \\
\hline \multicolumn{2}{|l|}{ Bobot calon induk F0 kontrol internal (g) } \\
\hline Weight of non selected $F 0(g)$ & 515.38 \\
\hline \multicolumn{2}{|l|}{ Diferensial seleksi (g) } \\
\hline Differensial of selection $(\mathrm{g})$ & 305.16 \\
\hline \multicolumn{2}{|l|}{ Bobot awal rata-rata populasi F1 terseleksi (g) } \\
\hline Initial weight of selected F1 (g) & 30.00 \\
\hline \multicolumn{2}{|l|}{ Bobot akhir rata-rata populasi F1 terseleksi (g) } \\
\hline Final weight of selected F1 (g) & 262.56 \\
\hline \multicolumn{2}{|l|}{ Koefisien variasi populasi F1 terseleksi (\%) } \\
\hline Coeffisien of variation of selected F1 (\%) & 58.55 \\
\hline \multicolumn{2}{|l|}{ Bobot awal rata-rata populasi F1 kontrol (g) } \\
\hline Initial weight of non selected F1 (g) & 30.00 \\
\hline \multicolumn{2}{|l|}{ Bobot akhir rata-rata populasi F1 kontrol (g) } \\
\hline Final weight of non selected F1 (g) & 244.72 \\
\hline \multicolumn{2}{|l|}{ Koefisien variasi popuasi F1 kontro (\%) } \\
\hline Coeffisien of variation of non selected F1 (\%) & 62.50 \\
\hline \multicolumn{2}{|l|}{ Respons seleksi F0 ke F1 (g) } \\
\hline Response to selection (g) & 17.84 \\
\hline \multicolumn{2}{|l|}{ Peningkatan genetic F0 ke F1 (\%) } \\
\hline Genetic gain $(\%)$ & 7.29 \\
\hline \multicolumn{2}{|l|}{ Heritabilitas nyata F0 } \\
\hline Realized heritability FO & 0.06 \\
\hline
\end{tabular}

nilai laju pertumbuhan spesifik yang diperoleh selama masa percobaan disajikan pada Gambar 1 dan Gambar 2.

Berdasarkan Tabel 1 terlihat bahwa populasi F1 terseleksi mempunyai bobot rata-rata sebesar 262,56 g lebih baik dibanding populasi F1 kontrol sebesar $244,72 \mathrm{~g}$. Meskipun nilai diferensial seleksi pada populasi induk F0 cukup besar $(305,16 \mathrm{~g})$ tetapi respons seleksi yang diperoleh relatif kecil, yaitu sebesar $17,84 \mathrm{~g}$. Nilai ini setara dengan peningkatan mutu genetik dari populasi F0 ke F1 sebesar 7,29\%. Rendahnya nilai respons seleksi dan peningkatan mutu genetik pada populasi hasil seleksi diduga disebabkan kecilnya nilai heritabilitas nyata F0 yang hanya sebesar 0,06 . Sebagaimana diketahui bahwa populasi dengan nilai heritabilitas nyata kurang dari 0,2 termasuk dalam kategori rendah sehingga seleksi individu pada populasi tersebut tidak efektif (Tave, 1993; Hardjosubroto, 1994; dan Noor, 2000). Heritabilitas adalah nilai yang menyatakan perbandingan pengaruh ragam genotipe terhadap ragam fenotipe. Semakin tinggi nilai heritabilitas berarti pengaruh genotipe terhadap keragaan populasi tersebut semakin besar dan sebaliknya jika nilai heritabilitas semakin rendah menunjukkan bahwa keragaan populasi tersebut sangat dipengaruhi oleh lingkungan. Nilai heritabilitas sebesar 0,06 ini menunjukkan tingginya pengaruh lingkungan terhadap keragaan benih hasil seleksi dibandingkan pengaruh genotipe yang diturunkan melalui induk. Keragaan pertumbuhan kedua populasi benih F1 selama empat bulan pemeliharaan disajikan pada Gambar 1.

Berdasarkan Gambar 1 terlihat bahwa keragaan populasi benih $\mathrm{F} 1$ terseleksi dan $\mathrm{F} 1$ kontrol relatif sama sejak awal hingga akhir pemeliharaan. Selisih bobot rata-rata induk F0 terseleksi dengan bobot rata-rata induk populasi kontrol (diferensial seleksi) yang terpaut cukup jauh tidak mampu menghasilkan keturunan dengan keragaan yang lebih baik dibanding populasi benih kontrol. Seperti sudah dijelaskan sebelumnya bahwa populasi induk F0 mempunyai nilai heritabilitas nyata sangat rendah sehingga kualitas genetik induk terseleksi tidak banyak berpengaruh terhadap keragaan keturunan yang dihasilkan.

Berdasarkan Tabel 2 terlihat bahwa populasi F2 hasil seleksi mempunyai bobot rata-rata sebesar 230,85 g lebih baik dibanding populasi kontrol sebesar 171,63 g. 


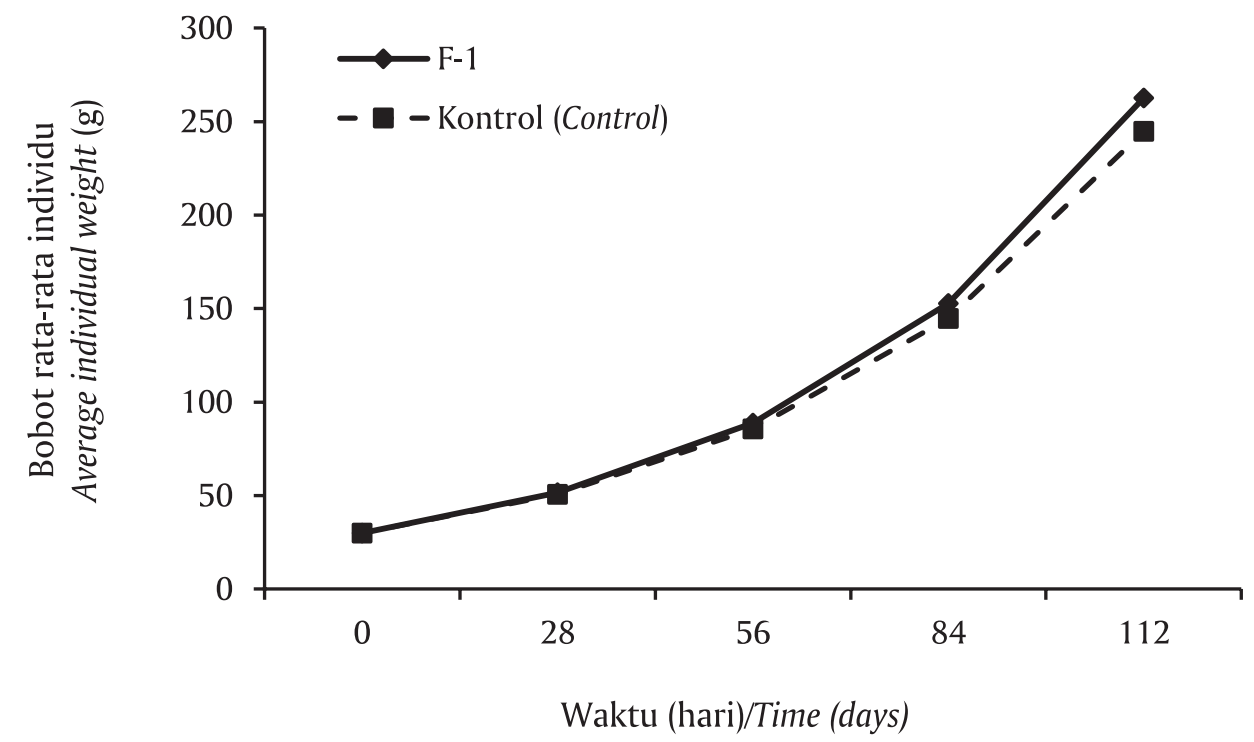

Gambar 1. Keragaan pertumbuhan populasi F1 terseleksi dan F1 kontrol selama empat bulan masa pembesaran

Picture 1. Growth performance of selected and non selected F1 for four months cultured

Tabel 2. Analisis beberapa parameter fenotipe dan genotipe populasi F2 hasil seleksi famili F1 pada ikan mas

Table 2. Phenotype and genotype parameters of F2 population from family selected $F 1$

\begin{tabular}{|c|c|}
\hline Parameter (Parameters) & Nilai (Values) \\
\hline $\begin{array}{l}\text { Bobot awal rata-rata populasi F-2 terseleksi } \\
\text { Initial weight of selected F-2 (g) }\end{array}$ & 30.00 \\
\hline $\begin{array}{l}\text { Bobot akhir rata-rata populasi F-2 terseleksi } \\
\text { Final weight of selected F- } 2 \text { (g) }\end{array}$ & 230.85 \\
\hline $\begin{array}{l}\text { Koefisien variasi populasi F-2 terseleksi } \\
\text { Coeffisien of variation of selected F-2 (\%) }\end{array}$ & 31.83 \\
\hline $\begin{array}{l}\text { Bobot awal rata-rata populasi F-2 terseleksi } \\
\text { Initial weight of non selected F-2 (g) }\end{array}$ & \\
\hline $\begin{array}{l}\text { Bobot rata-rata populasi F- } 2 \text { kontrol } \\
\text { Final weight of non selected F-2 (g) }\end{array}$ & 171.63 \\
\hline $\begin{array}{l}\text { Koefisien variasi } \\
\text { Coeffisien of variation of non selected F-2 (\%) }\end{array}$ & 43.83 \\
\hline $\begin{array}{l}\text { Respons seleksi F-1 ke F-2 } \\
\text { Response of selection (g) }\end{array}$ & 59.23 \\
\hline $\begin{array}{l}\text { Peningkatan genetik F-1 ke F-2 } \\
\text { Genetic gain (\%) }\end{array}$ & 34.51 \\
\hline
\end{tabular}

Berdasarkan nilai-nilai tersebut, nilai respons seleksi yang diperoleh pada populasi hasil seleksi famili F1 ke F2 relatif besar, yaitu sebesar 59,23 g. Nilai ini setara dengan peningkatan mutu genetik dari populasi F1 ke F2 sebesar 34,51\%. Tingginya nilai respons seleksi dan genetic gain pada populasi hasil seleksi ini disebabkan aktivitas seleksi yang menggunakan metode seleksi famili. Pada seleksi famili, sebagian besar varian yang tidak diturunkan (non-heritable variance) seperti varian lingkungan $\left(V_{E}\right)$ akan berkurang, sehingga nilai rata-rata fenotipe famili akan mendekati nilai pemuliaan famili tersebut (Tave, 1993). Pada seleksi dengan metode within family ini sumber utama dari varian yang tidak diturunkan, yaitu varian lingkungan $\left(V_{E}\right)$ adalah sama untuk semua individu dalam famili tetapi berbeda antar famili. Artinya varian lingkungan $\left(V_{E}\right)$ akan berpengaruh 


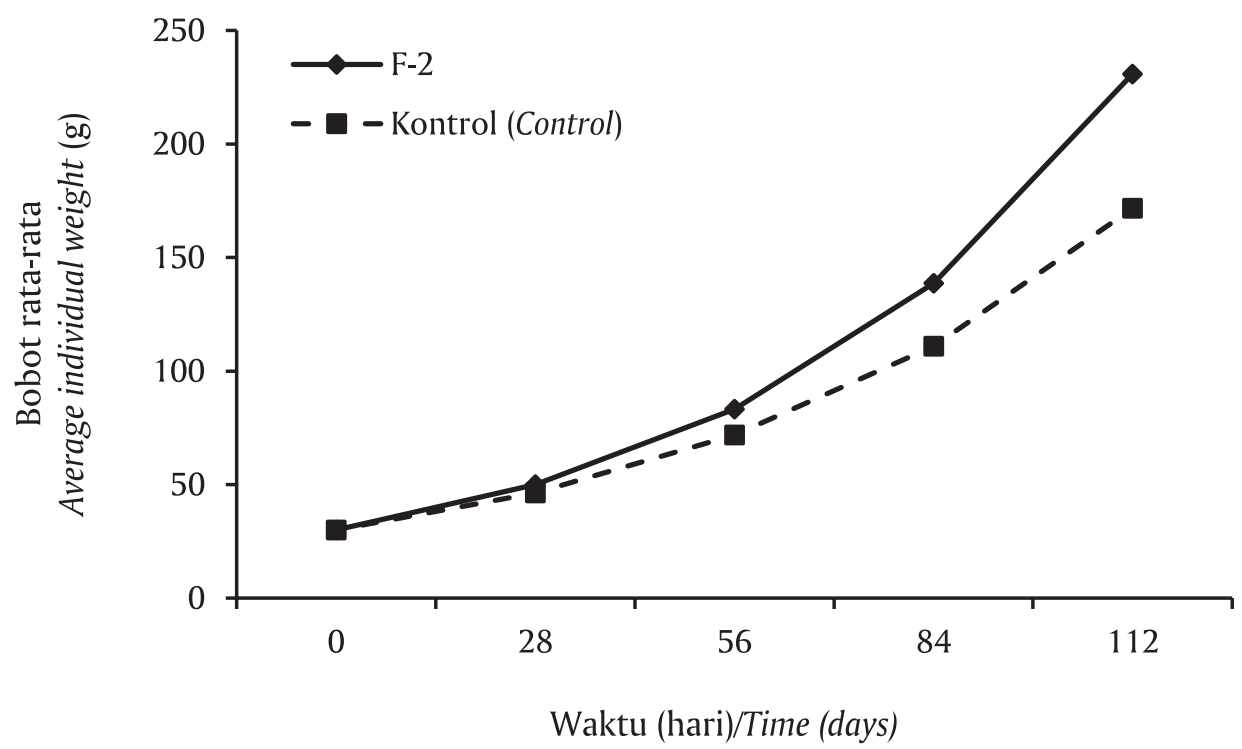

Gambar 2. Keragaan pertumbuhan populasi F2 hasil seleksi famili F1ikan mas selama empat bulan masa pembesaran

Picture 2. Growth performance of selected and non selected F2 for four months cultured

terhadap keragaan populasi pada tingkat famili tetapi bukan pada tingkat individu. Hal ini mengakibatkan pengaruh lingkungan terhadap individu menjadi lebih kecil dibandingkan pengaruh genetik. Seleksi famili dengan model within family seperti pada seleksi ikan mas di BPPI ini menjadi semakin efisien dibandingkan model between family karena jika sebagian besar varian fenotipe $\left(V_{p}\right)$ yang disebabkan oleh varian lingkungan $\left(V_{E}\right)$ terjadi pada tingkat famili, maka bisa jadi keragaan famili-famili terbaik pada populasi tersebut lebih banyak disebabkan oleh pengaruh lingkungan dibandingkan pengaruh genetik (Tave, 1993). Keragaan pertumbuhan populasi F2 hasil seleksi dan populasi kontrol selama empat bulan masa pembesaran disajikan pada Gambar 2.

Berdasarkan Gambar 2 terlihat bahwa keragaan populasi benih terseleksi dan kontrol relatif sama pada awal pemeliharaan hingga bulan kedua. Pada akhir bulan ketiga dan keempat, keragaan pertumbuhan populasi benih F2 hasil seleksi semakin cepat sehingga pada akhir kegiatan pembesaran mempunyai selisih bobot rata-rata yang cukup signifikan. Berdasarkan hasil analisis ini, laju pertumbuhan populasi benih F2 hasil seleksi diduga lebih banyak disebabkan oleh faktor genetik dibanding faktor lingkungan. Hal ini terbukti dengan kondisi lingkungan dan manajemen pemeliharaan yang sama, populasi benih hasil seleksi mempunyai laju pertumbuhan yang jauh lebih cepat dibanding populasi kontrol.

Rendahnya nilai respons seleksi dan peningkatan mutu genetik pada populasi dengan nilai heritabilitas rendah dapat diatasi dengan mengubah metode seleksi menggunakan model seleksi famili. Pelaksanaan seleksi famili pada populasi ikan mas di BPPI, Sukamandi berhasil mendapatkan respons seleksi sebesar 59,23 $\mathrm{g}$ atau setara dengan genetic gain sebesar 34,51\%. Peningkatan mutu genetik sebesar 34,51\% ini merupakan nilai yang sangat besar karena menurut Falconer \& Mackay (1996), Hardjosubroto (1994), Warwick et al. (1995) dan Tave (1996), peningkatan mutu genetik (genetic gain) pada induk melalui seleksi dapat mengubah rata-rata populasi turunannya sebesar $10 \%-15 \%$.Berdasarkan hasil yang diperoleh pada percobaan di atas, populasi dengan keragaman genetik dan nilai heritabilitas relatif rendah mampu menghasilkan populasi hasil seleksi dengan keragaan yang baik jika diseleksi menggunakan metode yang tepat.

\section{KESIMPULAN}

Seleksi individu pada populasi ikan mas yang mempunyai nilai heritabilitas 0,06 hanya menghasilkan respons seleksi sebesar 17,84 g setara dengan peningkatan genetik $7,29 \%$. Kondisi ini berhasil diperbaiki melalui seleksi famili yang menghasilkan respons seleksi sebesar 59,23 g setara dengan peningkatan mutu genetik $34,51 \%$.

\section{DAFTAR ACUAN}

Falconer, D.S., \& Mackay, T.F.C. (1996). Introduction to quantitative genetics. $4^{\text {th }}$ Ed. Longman. England, 464 pp.

Hardjosubroto, W. (1994). Aplikasi pemuliabiakan ternak di lapangan. PT Grasindo Indonesia. Jakarta, $284 \mathrm{hlm}$.

Noor, R.R. (2000). Genetika ternak. Penebar Swadaya. Jakarta, $200 \mathrm{hlm}$. 
Tave, D. (1993). Genetik for fish hatchery managers. Warwick, J.W., Astuti, M., \& Hardjasubroto, W. (1995). The AVI Publ. Comp. Inc. $2^{\text {nd }}$ ed. Connecticut, 418 Pemuliabiakan ternak. Gajahmada University Pres. pp. Yogyakarta, $485 \mathrm{hlm}$. 